JFRES Vol 1 (1) (2018): 1 - 9, DOI: http://dx.doi.org/10.32830/jfres.v1i1

I F E J Journal of Fiscal and Regional Economy Studies

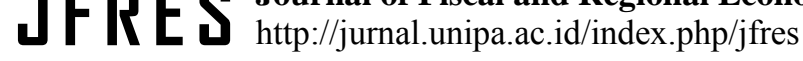

\title{
Faktor-Faktor Penentu Belanja Daerah Kabupaten/Kota di Provinsi Papua Barat
}

\author{
Marcus R. Maspaitella ${ }^{1}$, Lillyani M. Orisu ${ }^{2}$, Rahel Y. Tiwery ${ }^{3}$ \\ ${ }^{1}$ Dosen Fakultas Ekonomi Dan Bisnis, Universitas Papua, m.maspaitella@unipa.ac.id \\ ${ }^{2}$ Dosen Fakultas Ekonomi Dan Bisnis, Universitas Papua \\ ${ }^{3}$ Alumni Fakultas Ekonomi Dan Bisnis, Universitas Papua \\ Permalink/DOI: http://dx.doi.org/10.32830/jfres.v1i1.1013.g761
}

Received: April 2018; Accepted: June 2018; Published: September 2018

\begin{abstract}
Abstrak
Otonomi daerah adalah hak, wewenang, dan kewajiban daerah untuk mengatur dan mengurus sendiri urusan pemerintahannya. Implikasinya adalah bahwa daerah diberikan tanggung jawab dan wewenang untuk memenuhi kebutuhan masyarakat serta menggali segala potensi yang ada di daerah, guna mendukung kemampuan keuangan daerah yang menjadi modal pembiayaan dan penyelenggaraan pemerintah. Penelitian ini bertujuan untuk menganalisis pengaruh pendapatan asli daerah, dana perimbangan, dan lain-lain pendapatan yang sah terhadap belanja daerah kabupaten/kota di Papua Barat pada periode 2010-2015. Jumlah sampel penelitian ini adalah 7 kabupaten/kota. Estimasi model dianalisis dengan menggunakan regresi data panel. Hasil penelitian menunjukkan bahwa dana perimbangan dan lain-lain pendapatan yang sah berpengaruh positif dan signifikan terhadap belanja daerah. Sedangkan pendapatan asli daerah mempunyai pengaruh positif, namun tidak signifikan terhadap belanja daerah kabupaten/kota di Papua Barat.
\end{abstract}

Kata kunci: belanja daerah, PAD, dana perimbangan, lain-lain pendapatan yang sah

\begin{abstract}
Regional autonomy has provided a rightful authority for local governments to set and manage their own governmental affairs. The implication derived from this regulation is that local governments have to fulfill the regions' needs as well as to explore much more potentials owned. This can enhance the capacity of local governments that could be a useful capital in financing operational programs. This research aims to analyse the influence of region own source revenue, balance fund, and other lawful local revenues on local government expenditure of regencies and city in Papua Barat province between 2010 and 2015. Sample in this research includes six regencies and one city. Panel data regression was employed to estimate the fitted model. The result indicated that the effects of balance fund and other lawful local revenues were positive and significant, whereas the influence of region own source revenue was not significant on government expenditure of regency/city in Papua Barat.
\end{abstract}

Keywords: governement expenditure, region own revenue, balance fund, other lawful local revenues

How to Cite: Maspaitella, M.R., Orisu, L.M., Tiwery, R.Y. (2018). Faktor-Faktor Penentu Belanja Daerah Kabupaten/Kota di Provinsi Papua Barat. JFRES: Journal of Fiscal and Regional Economy Studies, 1 (1), 1-9. doi:https:// dx.doi.org/10.32830/jfres.v1i1.1013.g761 


\section{PENDAHULUAN}

Menurut Undang-undang Nomor 32 Tahun 2004 tentang Pemerintahan Daerah, otonomi daerah adalah hak, wewenang, dan kewajiban daerah otonom untuk mengatur dan mengurus sendiri urusan pemerintahan dan kepentingan masyarakat setempat. Implikasi dari kebijakan otonomi daerah tersebut adalah daerah diberikan tanggung jawab dan wewenang untuk memenuhi kebutuhan masyarakat serta kewenangan untuk memanfaatkan peluang untuk menggali segala potensi daerah yang dimiliki, guna mendukung kemampuan keuangan daerah sebagai modal pembiayaan dan penyelenggaraan pemerintah di daerah. Pemberian wewenang yang lebih luas dalam penyelenggaraan pemerintah di daerah berdampak bagi perkembangan pembangunan daerah-daerah di Indonesia yang berimplikasi pada peningkatan pelayanan publik, kesejahteraan, dan jaminan hidup masyarakat yang lebih baik.

Menurut Halim dalam Rahmawati (2010), dalam rangka penyelenggaraan pemerintah dan pelayanan kepada masyarakat berdasarkan asas desentralisasi, kepada daerah diberi kewenangan untuk memungut pajak/retribusi dan mengelola sumberdaya alam. Sumber dana bagi daerah terdiri dari pendapatan asli daerah (PAD), dana perimbangan, lain-lain pendapatan yang sah, dan dana dekonsentrasi. Tiga sumber pertama langsung dikelola oleh pemerintah daerah melalui anggaran pendapatan dan belanja daerah (APBD), sedangkan dana dekonsentrasi dikelola oleh pemerintah pusat melalui kerja sama dengan pemerintah daerah.

Untuk pelaksanaan kewenangan pemerintah daerah, pemerintah pusat akan mentransfer dana perimbangan yang terdiri dari dana alokasi umum (DAU), dana alokasi khusus (DAK), dan bagian daerah dari dana bagi hasil yang terdiri dari pajak dan sumber daya alam. Kebijakan penggunaan semua dana tersebut diserahkan kepada pemerintah daerah. Undang-undang No. 32 Tahun 2004 juga menyatakan bahwa dana transfer dari pemerintah pusat diharapkan dapat digunakan secara efektif dan efisien oleh pemerintah daerah untuk meningkatkan pelayanan kepada masyarakat.
Dalam pembentukan keuangan pemerintah daerah, selain adanya komponen pendapatan ada pula komponen lainnya yang termasuk di dalamnya yaitu pengeluaran pemerintah atau belanja daerah yang digunakan untuk mendanai pelaksanaan urusan pemerintah. Berdasarkan Peraturan Pemerintah No. 58 Tahun 2005, belanja daerah adalah semua kewajiban daerah yang diakui sebagai pengurang nilai kekayaan bersih dalam periode tahun anggaran yang bersangkutan. Belanja daerah dipergunakan dalam rangka mendanai pelaksanaan urusan pemerintah yang menjadi kewenangan provinsi atau kabupaten/kota yang terdiri dari urusan wajib dan urusan pilihan yang ditetapkan dengan ketentuan perundang-undangan. Urusan wajib adalah urusan yang sangat mendasar yang berkaitan dengan hak dan pelayanan dasar kepada masyarakat yang wajib diselenggarakan oleh pemerintah daerah. Sedangkan urusan pilihan adalah urusan pemerintah yang secara nyata ada dan berpotensi untuk menigkatkan kesejahteraan masyarakat sesuai kondisi, kekhasan, dan potensi keunggulan daerah. Belanja daerah menurut kelompok belanja terdiri dari belanja langsung dan belanja tidak langsung. Belanja langsung adalah komponen belanja yang terdiri dari belanja pegawai, belanja barang dan jasa, dan belanja modal. Sedangkan belanja tidak langsung merupakan komponen belanja yang terdiri dari belanja pegawai, belanja bunga, belanja hibah, belanja bantuan sosial, belanja bagi hasil, belanja bantuan keuangan, dan belanja tidak terduga.

Sebagai salah satu daerah otonom yang relatif baru, Papua Barat diharapkan dapat memanfaatkan kewenangan yang diberikan dalam rangka melakukan optimalisasi sumber-sumber pendapatan dan belanja daerah. Dalam kurun waktu 2010 sampai 2015, realisasi belanja daerah provinsi Papua Barat meningkat secara gradual dari Rp. 3,1 triliun menjadi Rp. 6,8 triliun. Dari sisi pendapatan, terjadi peningkatan PAD dari Rp. 125,7 miliar pada tahun 2010 menjadi Rp. 322,7 miliar pada tahun 2015. Dana perimbangan meningkat dari Rp. 1.4 triliun pada tahun 2010 menjadi hampir Rp 3 triliun pada tahun 2014. Jumlah transfer dana perimbangan kemudian mengalami penurunan hingga mencapai Rp. 
2,4 triliun pada 2015. Lain-lain pendapatan yang sah yang diperoleh oleh pemerintah daerah Papua Barat mengalami peningkatan dari 1,8 triliun pada tahun 2010 menjadi lebih dari Rp. 3 triliun pada tahun 2015 (Tabel 1).

Berdasarkan uraian diatas, maka pertanyaan penelitian yang ingin dijawab dalam penelitian ini adalah apa saja faktor-faktor penentu belanja daerah di provinsi Papua Barat. Dengan mengeksplorasi basis data APBD di level pemerintah kabupaten/kota, penelitian ini bertujuan untuk menganalisis pengaruh $\mathrm{PAD}$, dana perimbangan, dan lain-lain pendapatan yang sah terhadap belanja daerah kabupaten/kota di Papua Barat periode tahun 2010-2015.

\section{METODE PENELITIAN}

\section{Sampel dan Data}

Sampel penelitian ini meliputi terdiri dari 6 kabupaten dan 1 kota di wilayah provinsi Papua Barat, diantaranya Kabupaten Fakfak, Kabupaten Manokwari, Kabupaten Teluk Bintuni, Kabupaten Teluk Wondama, Kabupaten Raja Ampat, Kabupaten Maybrat dan Kota Sorong.

Data yang digunakan dalam penelitian ini berupa data kuantitatif tentang APBD kabupaten/kota. Penelitian ini menggunakan jenis data panel yaitu gabungan antara data time series (6 tahun) dan data cross section ( 7 kabupaten/kota), sehingga diperoleh sebanyak 42 data set untuk diobservasi. Data sekunder yang digunakan dalam penelitian ini diperoleh dari instansi terkait, seperti Badan Pusat Statistik (BPS) kabupaten/kota di Papua Barat. Data yang dianalisis meliputi realisasi belanja daerah, realisasi $\mathrm{PAD}$, realisasi dana perimbangan, dan realisasi lain-lain pendapatan yang sah kabupaten/kota di provinsi Papua Barat periode 2010-2015.

\section{Metode Analisis Data}

Model regresi data panel (panel data regression) digunakan untuk mengestimasi model yang diuji. Data panel dapat digunakan untuk mengatasi ketersediaan data untuk mewakili variabel yang digunakan dalam penelitian (Baltagi, 2005). Jika ditemukan bentuk dalam series yang pendek sehingga proses pengolahan data time series tidak dapat dilakukan karena jumlah data yang minim. Demikian pula bila ditemukan bentuk data dengan jumlah unit cross section yang terbatas, maka sulit melakukan pengolahan data untuk mendapatkan informasi perilaku dari model yang diteliti. Dalam analisis regresi data panel, terdapat tiga pendekatan, yakni Common Efect, Fixed Effect, dan Random Effect.

Model umum analisis regresi data panel dapat diformulasikan sebagai berikut:

$Y_{i, t}=a_{i}+\beta X_{i, t}+e_{i, t}$

dimana :

$a_{i}$ : individual effect

$X_{i, t}:$ vektor variabel penjelas

$e_{i, t}:$ error term

$i \quad$ : jumlah observasi antar individu

$t$ : jumlah observasi runtun waktu

Tabel 1. Realisasi belanja daerah, PAD, dana perimbangan dan lain-lain pendapatan yang sah Provinsi Papua Barat, 2010-2015 (.000 Rupiah)

\begin{tabular}{ccccc}
\hline Tahun & Belanja Daerah & PAD & Dana Perimbangan & $\begin{array}{c}\text { Lain-lain Pendapatan } \\
\text { yang Sah }\end{array}$ \\
\hline 2010 & 3.104 .771 .915 & 125.774 .328 & 1.462 .347 .937 & 1.819 .680 .723 \\
2011 & 3.629 .959 .955 & 152.163 .909 & 1.483 .865 .431 & 2.063 .854 .826 \\
2012 & 3.898 .931 .911 & 175.450 .133 & 1.516 .156 .702 & 2.181 .781 .583 \\
2013 & 4.512 .430 .215 & 236.282 .889 & 2.992 .755 .350 & 2.408 .658 .394 \\
2014 & 5.428 .849 .491 & 306.674 .698 & 2.783 .645 .235 & 2.672 .028 .269 \\
2015 & 6.880 .166 .676 & 322.799 .298 & 2.496 .263 .896 & 3.021 .289 .926 \\
\hline
\end{tabular}

Sumber: Statistik Keuangan Pemerintah Daerah Papua Barat, 2015 


\section{Hipotesis}

Adapun hipotesis yang diuji dalam regresi data panel adalah sebagai berikut:

$\mathrm{H}_{0}: \beta=0$, artinya tidak terdapat pengaruh nyata dari variabel bebas (PAD, dana perimbangan, dan lain-lain pendapatan yang sah) terhadap variabel tak bebas (belanja daerah), dengan $\alpha=1 \%$.

$\mathrm{H}_{1}: \beta \neq 0$, artinya terdapat pengaruh nyata dari variabel bebas (PAD, dana perimbangan, dan lain-lain pendapatan yang sah) terhadap variabel tak bebas (belanja daerah), dengan $\alpha=1 \%$.

Software Eviews 7 digunakan dalam mengestimasi model regresi data panel (common effect, fixed effect, dan random effect). Kemudian akan dilakukan tiga uji kriteria pemilihan model penelitian yaitu: Uji Statistik F (uji Chow), Uji Langrange Multiplier (LM), dan Uji Hausman untuk menentukan model mana yang paling sesuai untuk mengestimasi pengaruh PAD, dana perimbangan dan lain-lain pendapatan yang sah terhadap belanja daerah.

\section{HASIL DAN PEMBAHASAN}

\section{Analisis Deskriptif Variabel}

Bagian ini menyajikan deskripsi variabel belanja daerah, PAD, dana perimbangan, dan lain-lain pendapatan yang sah di tujuh kabupaten/kota yang menjadi sampel penelitian ini. Tabel 2 menyajikan data perkembangan realisasi belanja daerah di daerah sampel.

Tabel 2 menunjukkan bahwa secara umum belanja daerah mengalami peningkatan dari tahun 2010 ke tahun 2015. Kabupaten/Kota yang mengalami peningkatan belanja daerah yang cukup pesat adalah Kabupaten Teluk Bintuni, yakni dari Rp. 712 miliar pada tahun 2010 menjadi hampir mendekati Rp. 2 triliun pada tahun 2015. Selain itu, tren peningkatan belanja daerah Kabupaten Fakfak juga sangat signifikan, yakni dari Rp. 627 miliar pada tahun 2010, dan mendekati dua kali lipat dalam kurun waktu lima tahun, menjadi Rp. 1,171 triliun. Beberapa kabupaten mengalami kenaikan belanja daerah secara gradual, seperti pada Kabupaten Manokwari, Raja Ampat, dan Kota Sorong.

Tabel 3 menunjukkan realisasi PAD kabupaten/kota di Papua Barat tahun 2010-2015. Dari keseluruhan kabupaten/kota tersebut, dilihat bahwa PAD setiap kabupaten berfluktuatif kecuali Kabupaten Teluk Bintuni yang setiap tahunnya mengalami peningkatan. Kota Sorong merupakan salah satu daerah yang memiliki PAD tertinggi jika dibandingkan dengan daerahdaerah lainnya di Papua Barat, meskipun pada tahun 2010 dan 2011 didominasi oleh Kabupaten Manokwari dan Raja Ampat. Pendapatan yang tinggi tersebut ditopang oleh kontribusi pajak, retribusi, lain-lain pendapatan asli daerah yang sah, dan hasil pengelolaan kekayaan daerah.

Pada tahun 2010, PAD tertinggi adalah Kabupaten Manokwari (Rp. 28,763 miliar), diikuti oleh Kota Sorong (Rp. 26,526 miliar), dan Kabupaten Fakfak (Rp. 20,557 miliar). Dalam kurun waktu lima tahun terjadi perubahan realisasi PAD, dimana PAD tertinggi pada tahun 2015 adalah Kota Sorong (Rp. 86,223 miliar), diikuti Kabupaten Fakfak (Rp. 76,400 miliar), dan Kabupaten Teluk Bintuni (Rp. 54,094 miliar). Secara umum terjadi peningkatan PAD

Tabel 2. Realisasi Belanja Daerah Kabupaten/Kota di Papua Barat (Miliar Rupiah)

\begin{tabular}{lcccrrr}
\hline Kabupaten/ Kota & $\mathbf{2 0 1 0}$ & $\mathbf{2 0 1 1}$ & $\mathbf{2 0 1 2}$ & $\mathbf{2 0 1 3}$ & \multicolumn{1}{c}{$\mathbf{2 0 1 4}$} & \multicolumn{1}{c}{$\mathbf{2 0 1 5}$} \\
\hline Manokwari & 800.653 .765 & 799.990 .368 & 799.990 .368 & 974.640 .590 & 898.381 .430 & 915.066 .110 \\
Fakfak & 627.839 .578 & 643.462 .060 & 716.506 .964 & 784.042 .666 & 784.042 .666 & 1.171 .868 .918 \\
Kota Sorong & 524.495 .450 & 548.067 .038 & 700.176 .812 & 711.692 .905 & 842.869 .705 & 928.464 .430 \\
Teluk Bintuni & 712.910 .225 & 836.290 .165 & 879.371 .481 & 1.103 .571 .475 & 1.309 .708 .438 & 1.993 .846 .234 \\
Teluk Wondama & 305.913 .934 & 498.859 .055 & 517.742 .725 & 586.005 .582 & 601.794 .995 & 706.962 .467 \\
Raja Ampat & 673.087 .102 & 664.885 .883 & 704.918 .421 & 796.266 .594 & 962.176 .327 & 982.163 .237 \\
Maybrat & 250.245 .361 & 389.614 .678 & 436.178 .783 & 374.057 .430 & 610.980 .959 & 807.486 .938 \\
\hline
\end{tabular}

Sumber : Kabupaten/Kota di Provinsi Papua Barat Dalam Angka, 2011-2016. 
Tabel 3. Realisasi PAD Kabupaten/Kota di Papua Barat (Miliar Rupiah)

\begin{tabular}{lrrrrrr}
\hline Kabupaten/ Kota & \multicolumn{1}{c}{$\mathbf{2 0 1 0}$} & \multicolumn{1}{c}{$\mathbf{2 0 1 1}$} & \multicolumn{1}{c}{$\mathbf{2 0 1 2}$} & \multicolumn{1}{c}{$\mathbf{2 0 1 3}$} & \multicolumn{1}{c}{$\mathbf{2 0 1 4}$} & \multicolumn{1}{c}{$\mathbf{2 0 1 5}$} \\
\hline Manokwari & 28.763 .973 & 21.959 .986 & 28.044 .312 & 19.845 .240 & 70.303 .180 & 30.215 .280 \\
Fakfak & 20.557 .095 & 14.839 .034 & 14.839 .034 & 23.288 .314 & 48.739 .897 & 76.400 .161 \\
Kota Sorong & 26.526 .551 & 25.142 .232 & 98.443 .362 & 56.277 .723 & 100.020 .643 & 86.223 .381 \\
Teluk Bintuni & 8.882 .412 & 17.533 .957 & 22.206 .764 & 31.143 .598 & 42.627 .971 & 54.094 .801 \\
Teluk Wondama & 6.460 .742 & 3.760 .680 & 8.850 .295 & 8.476 .327 & 14.345 .589 & 16.533 .112 \\
Raja Ampat & 19.566 .845 & 25.372 .972 & 16.988 .535 & 23.500 .181 & 24.143 .801 & 23.900 .000 \\
Maybrat & 10.825 .863 & 3.417 .259 & 3.158 .936 & 9.594 .521 & 10.912 .089 & 18.529 .166 \\
\hline
\end{tabular}

Sumber : Kabupaten/Kota di Provinsi Papua Barat Dalam Angka, 2011-2016.

Kabupaten/Kota di Papua Barat selama periode 2010-2015. Dengan demikian diharapkan pemerintah daerah kabupaten/kota di provinsi dapat memanfaatkan semua potensi yang ada di daerahnya masing-masing.

Dana Perimbangan menurut Undang-undang No. 33 Tahun 2004 adalah dana yang bersumber dari pendapatan APBN yang dialokasikan kepada daerah untuk mendanai kebutuhan daerah dalam rangka pelaksanaan desentralisasi. Realisasi dana perimbangan kabupaten/kota di Provinsi Papua Barat tahun 2010-2015 disajikan pada Tabel 4. Dana perimbangan yang diterima kabupaten/kota di Papua Barat dalam perkembangannya mengalami fluktuasi, meskipun secara umum dari tahun 2010 ke tahun 2015 terlihat mengalami peningkatan. Pada tahun 2010, dana perimbangan tertinggi diterima oleh Kabupaten Teluk Bintuni (Rp. 641,040 miliar), selanjutnya Kabupaten Manokwari (Rp. 568,964 miliar), dan Kabupaten Fakfak (Rp. 481,006 miliar). Pada tahun 2015, dana perimbangan tertinggi adalah Kabupaten Teluk Bintuni (Rp. 1,350 triliun), diikuti Kabupaten Raja Ampat (Rp. 859,122 miliar), dan Kabupaten Fakfak (Rp. 832,076 miliar). Secara keseluruhan, tingginya Dana Perimbangan ditopang oleh dana alokasi umum (DAU) yang merupakan salah satu bentuk dana transfer dari pemerintah pusat.

Tabel 5 menyajikan data realisasi lain-lain pendapatan yang sah kabupaten/kota di Papua Barat tahun 2010-2015. Lain-lain Pendapatan yang sah merupakan salah satu penerimaan daerah yang lebih tinggi dibandingkan dengan
PAD. Komponen lain-lain pendapatan yang sah terdiri dari pendapatan hibah, dana darurat, dana bagi hasil pajak dari provinsi dan pemerintah daerah lainnya, dana penyesuaian, dan dana otonomi khusus.

Data pada Tabel 5 menunjukkan perkembangan penerimaan lain-lain pendapatan yang sah dari tahun 2010-2015 yang berfluktuatif, meskipun demikian pada tahun 2015 penerimaan pendapatannya lebih tinggi dari tahun 2010, kecuali Kabupaten Raja Ampat yang mengalami penurunan. Pada tahun 2015, penerimaan lainlain pendapatan yang sah tertinggi adalah Kabupaten Fakfak (Rp. 352,568 miliar). Hal ini ditopang oleh adanya kontribusi yang tinggi pula dari komponen pendapatan dana bagi hasil pajak dari provinsi dan/atau kabupaten lainnya (Rp.194,159 miliar) dan komponen pendapatan dari dana penyesuaian dan otonomi daerah (Rp.157,159 miliar). Kabupaten Raja Ampat adalah daerah yang memiliki lain-lain pendapatan yang sah terendah, yakni Rp. 109,140 miliar. Secara keseluruhan, tingginya lain-lain pendapatan daerah yang sah tahun 2015 pada kabupaten/kota tersebut ditopang oleh tingginya dana penyesuaian dan otonomi daerah.

\section{Hasil Estimasi Model Data Panel}

Estimasi regresi data panel merupakan teknik pengolahan data yang digunakan dalam penelitian ini. Terdapat beberapa pendekatan yang digunakan untuk mengestimasi model regresi data panel yaitu common effect, fixed effect, dan random effect (lihat Tabel 6). 
Tabel 4. Realisasi Dana Perimbangan Kabupaten/Kota di Papua Barat (Miliar Rupiah)

\begin{tabular}{|c|c|c|c|c|c|c|}
\hline $\begin{array}{l}\text { Kabupaten/ } \\
\text { Kota }\end{array}$ & 2010 & 2011 & 2012 & 2013 & 2014 & 2015 \\
\hline Manokwari & 568.964 .837 & 618.521 .740 & 704.456 .081 & 825.564 .800 & 545.433 .800 & 669.563 .140 \\
\hline Fakfak & 481.006 .338 & 556.692 .639 & 556.692 .639 & 680.926 .175 & 764.683 .378 & 832.076 .914 \\
\hline Kota Sorong & 342.710 .817 & 401.315 .578 & 486.711 .341 & 555.319 .265 & 559.912 .560 & 578.302 .914 \\
\hline Teluk Bintuni & 641.040 .738 & 732.137 .687 & 682.713 .998 & 1.157 .454 .382 & 1.081 .628 .754 & 1.350 .640 .564 \\
\hline Teluk Wondama & 326.202 .067 & 266.124 .123 & 437.806 .715 & 522.288 .499 & 528.655 .677 & 514.095 .189 \\
\hline Raja Ampat & 469.276 .403 & 529.108 .561 & 592.897 .060 & 670.820 .236 & 767.654 .577 & 859.122 .624 \\
\hline Maybrat & 190.268 .450 & 399.448 .362 & 346.855 .514 & 335.930 .930 & 501.207 .418 & 508.258 .609 \\
\hline
\end{tabular}

Sumber : Kabupaten/Kota di Provinsi Papua Barat Dalam Angka, 2011-2016.

Tabel 5. Realisasi Lain-lain Pendapatan yang Sah Kabupaten/Kota di Papua Barat (Miliar Rupiah)

\begin{tabular}{|c|c|c|c|c|c|c|}
\hline $\begin{array}{c}\text { Kabupaten/ } \\
\text { Kota }\end{array}$ & 2010 & 2011 & 2012 & 2013 & 2014 & 2015 \\
\hline Manokwari & 161.117 .944 & 224.253 .885 & 166.835 .166 & 180.276 .700 & 227.126 .470 & 282.315 .000 \\
\hline Fakfak & 123.671 .900 & 103.483 .275 & 103.483 .275 & 148.731 .130 & 179.483 .952 & 352.568 .722 \\
\hline Kota Sorong & 172.145 .331 & 144.468 .369 & 189.672 .323 & 151.292 .453 & 207.579 .604 & 199.513 .853 \\
\hline Teluk Bintuni & 107.350 .226 & 130.480 .319 & 139.896 .949 & 227.575 .911 & 376.815 .104 & 351.103 .148 \\
\hline Teluk Wondama & 66.532 .022 & 89.018 .923 & 69.509 .086 & 76.262 .359 & 100.959 .162 & 125.419 .629 \\
\hline Raja Ampat & 143.426 .629 & 114.635 .947 & 117.515 .233 & 146.032 .925 & 147.407 .581 & 109.140 .613 \\
\hline Maybrat & 58.581 .175 & 94.421 .743 & 82.293 .452 & 44.933 .489 & 153.794 .007 & 218.570 .778 \\
\hline
\end{tabular}

Sumber : Kabupaten/Kota di Provinsi Papua Barat Dalam Angka, 2011-2016.

Hasil analisis dengan pendekatan common effect menggunakan asumsi bahwa koefisien baik intersep maupun slope adalah sama antar waktu dan antar kabupaten/kota. Hasil regresi menunjukkan bahwa ketiga variabel bebas berpengaruh positif terhadap belanja daerah, tetapi hanya dana perimbangan dan lain-lain pendatatan yang sah yang berpengaruh signifikan terhadap belanja daerah. Nilai F-statistic yang lebih rendah dari 0.01 menunjukkan bahwa secara simultan belanja daerah dipengaruhi oleh ketiga variabel yang diiuji. Nilai koefisien determinasi $\left(\mathrm{R}^{2}\right)$ sebesar 0,92 berarti bahwa model mampu menjelaskan variasi belanja daerah sebesar $92 \%$.

Analisis dengan metode fixed effect menggunakan asumsi bahwa intersep berbeda antar kabupaten/kota, sedangkan slope tetap sama antar kabupaten/kota. Hasil pengujian regresi data panel dengan pendekatan ini menunjukkan bahwa variabel PAD, dana perimbangan, dan lain-lain pendapatan yang sah memberikan pengaruh yang positif terhadap belanja daerah. Namun, berdasarkan uji t, variabel dana perimbangan dan lain-lain pendapatan yang sah yang berpengaruh signifikan pada $\alpha=1 \%$. Hasil uji $\mathrm{F}$ menunjukkan bahwa secara serempak ketiga variabel independen yang dimasukan ke dalam model berpengaruh signifikan terhadap belanja daerah, dengan nilai koefisien determinasi $\left(\mathrm{R}^{2}\right)$ sebesar $93 \%$.

Hasil analisis dengan menggunakan pendekatan random effect menggunakan asumsi bahwa intersep antara kabupaten/kota adalah berbeda. Hasil regresinya tidak berbeda dengan kedua metode sebelumnya, yakni PAD tidak berpengaruh signifikan terhadap belanja daerah, sedangkan dana perimbangan dan lain-lain pendapatan yang sah menunjukkan pengaruh signifikan. Uji $\mathrm{F}$ menunjukkan bahwa ketiga variabel secara bersama-sama berpengaruh signifikan terhadap belanja daerah dengan $\mathrm{R}^{2}$ sebesar $92 \%$. 
Tabel 6. Hasil Estimasi Data Panel

\begin{tabular}{|c|c|c|c|c|}
\hline \multicolumn{5}{|l|}{ Model Common Effect } \\
\hline Variabel & Koefisien & Std. Error & t-Statistic & Prob. \\
\hline (Constant) & 0,937071 & 0,547697 & 1,710931 & 0,0952 \\
\hline $\mathrm{X} 1$ (PAD) & 0,037476 & 0,030103 & 1,244925 & 0,2208 \\
\hline X2 (Dana Perimbangan) & 0,663755 & 0,062455 & 10,62769 & 0,0000 \\
\hline X3 (Lain Pdptn yang sah) & 0,244796 & 0,062738 & 3,901905 & 0,0004 \\
\hline R-squared & 0,923905 & & Sum squared resid & 0,084354 \\
\hline Adjusted R-squared & 0,917897 & & F-statistic & 153,7919 \\
\hline Durbin-Watson & 2,198754 & & Prob. (F-statistic) & 0,000000 \\
\hline \multicolumn{5}{|l|}{ Model Fixed Effect } \\
\hline Variabel & Koefisien & Std. Error & t-Statistic & Prob. \\
\hline (Constant) & 1,275250 & 0,874251 & 1,458677 & 0,1544 \\
\hline X1 (PAD) & 0,043373 & 0,043686 & 1,992844 & 0,3282 \\
\hline X2 (Dana Perimbangan) & 0,595633 & 0,096018 & 6,203337 & 0,0000 \\
\hline X3 (Lain Pdptn yang sah) & 0,280783 & 0,071931 & 3,903518 & 0,0005 \\
\hline R-squared & 0,930719 & & Sum squared resid & 0,076800 \\
\hline Adjusted R-squared & 0,911234 & & F-statistic & 47,76557 \\
\hline Durbin-Watson & 2,217567 & & Prob. (F-statistic) & 0,000000 \\
\hline \multicolumn{5}{|l|}{ Model Random Effect } \\
\hline Variabel & Koefisien & Std. Error & t-Statistic & Prob. \\
\hline (Constant) & 0,937071 & 0,569488 & 1,645463 & 0,1081 \\
\hline X1 (PAD) & 0,037476 & 0,031301 & 1,197288 & 0,2386 \\
\hline X2 (Dana Perimbangan) & 0,663755 & 0,064940 & 10,22103 & 0,0000 \\
\hline X3 (Lain Pdptn yang sah) & 0,244796 & 0,065234 & 3,752601 & 0,0006 \\
\hline R-squared & 0,923905 & & Sum squared resid & 0,084354 \\
\hline Adjusted R-squared & 0,917897 & & F-statistic & 153,7919 \\
\hline Durbin-Watson & 2,198754 & & Prob. (F-statistic) & 0,000000 \\
\hline
\end{tabular}

Sumber : Data diolah, 2018

\section{Pemilihan Model Estimasi}

Uji Chow diaplikasikan untuk memilih antara model common effect dan fixed effect. Hipotesisnya adalah bahwa metode common effect dipakai jika $F_{\text {hitung }}<\mathrm{F}_{\text {tabel, }}$, sebaliknya model fixed effect yang akan digunakan jika $F_{\text {hitung }}>F_{\text {tabel }}$. Hasil perhitungan nilai $\mathrm{F}$-statitic adalah sebagai berikut:

$$
\begin{aligned}
& \mathrm{F}_{\text {hitung }}=\frac{(\mathrm{RSSR}-\mathrm{USSR}) /(\mathrm{N}-1)}{\mathrm{USSR} /(\mathrm{NT}-\mathrm{N}-\mathrm{K})} \\
& \mathrm{F}_{\text {hitung }}=\frac{(0,084354-0.076800) /(7-1)}{0.076800 /(7 \times 6-7-3)} \\
& \mathrm{F}_{\text {hitung }}=0,5264
\end{aligned}
$$

Dari hasil estimasi uji Chow diperoleh nilai $\mathrm{F}_{\text {hitung }}=0,5246$ sementara nilai statistik $\mathrm{F}$ kritis dengan numerator $(\mathrm{N}-1)=6$ dan denumerator $(\mathrm{NT}-\mathrm{N}-\mathrm{K})=32$ pada $\alpha=5 \%$ adalah 2,399 . Karena $\mathrm{F}_{\text {hitung }}$ lebih kecil dari $\mathrm{F}_{\text {tabel }}$ maka model data panel yang tepat digunakan adalah common effect.

Untuk pemilihan model estimasi antara fixed effect dan random effect, digunakan uji Hausman. Hipotesisnya adalah bahwa model random effect diterima jika nilai Hausman lebih kecil dari nilai chi-square, sedangkan model fixed effect yang digunakan apabila nilai Hausman lebih besar dari nilai chi-square. Dari pengujian Hausman menggunakan Eviews 7 diperoleh nilai $c$-square statistik adalah 1,722. Nilai tersebut kemudian dibandingkan dengan nilai chi-square kritis/tabel pada $\alpha=5 \%$. Nilai chi-square statistik lebih kecil dari pada nilai chi-square kritis ( $\alpha=5 \%$ yaitu 7,814), sehingga model yang lebih baik digunakan adalah model random effect.

Uji Langrange Multiplier (LM) digunakan untuk mengetahui apakah model random effect lebih 
baik dari model common effect. Hipotesisnya adalah bahwa model common effect yang diterima apabila nilai LM lebih kecil dari nilai chi-square kritis, sebaliknya model random effect yang digunakan jika nilai LM lebih besar dari nilai chi-square kritis. Perhitungannya adalah sebagai berikut:

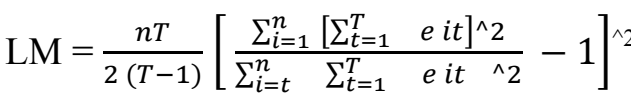

$\mathrm{LM}=51,45$

Nilai chi-square tabel dengan $\mathrm{df}=3$ dan $\alpha=5 \%$ adalah sebesar 7,814. Dengan demikian maka nilai LM statistic $(51,45)$ lebih besar dari nilai kritis chi-square $(7,814)$, sehingga estimasi yang tepat untuk model regresi data panel yaitu metode random effect.

Dari ketiga pengujian tersebut, maka metode data panel yang layak dan tepat untuk digunakan dalam menganalisis penentu belanja daerah kabupaten/kota di provinsi Papua Barat adalah model random effect. Model persamaannya adalah sebagai berikut:

$\mathrm{Y}_{\mathrm{it}}=0,937+0,037 \mathrm{X}_{1}+0,664 \mathrm{X}_{2}+0,245 \mathrm{X}_{3}+\mathrm{e}$

\section{Interpretasi Model dan Pembahasan}

Dari model yang dihasilkan, maka pengaruh variabel-variabel penentu belanja daerah kabupaten/kota di Papua Barat dapat dijelaskan secara lebih detail.

PAD berpengaruh positif pada $\alpha=1 \%$. Nilai koefisien sebasar 0.0375 menyatakan bahwa dalam kondisi ceteris paribus, kenaikan 1satuan pada PAD akan mengakibatkan penambahan sebesar 0,04 satuan (4\%) pada belanja daerah. Pengaruh PAD yang sangat kecil ini dibuktikan juga dengan uji signifikansi, dimana nilai $\mathrm{p}$ value cukup tinggi, yakni 0,2386 . Hasil ini juga mengkonfirmasi beberapa penelitian terdahulu seperti Maspaitella (2010), Rosy dan Gusti (2014), Dessy (2015), dan Ridho (2011) bahwa PAD tidak secara signifikan menentukan belanja daerah.

Dana perimbangan berpengaruh positif dan signifikan pada $\alpha=1 \%$ (sign. $=0,000$ ). Hal ini berarti bahwa dengan meningkatnya dana perimbangan akan berdampak positif terhadap belanja daerah. Koefisien regresi sebesar 0,664 artinya apabila terjadi kenaikan variabel dana perimbangan sebesar 1 satuan, dan kondisi lainnya dianggap tidak berubah, maka akan menaikkan jumlah belanja daerah sebesar 0,66 satuan (66\%). Implikasi dari hasil penelitian ini adalah bahwa daerah kabupaten/kota di Papua Barat masih memiliki ketergantungan fiskal yang sangat tinggi kepada transfer keuangan dari pemerintah pusat. Hasil ini juga sesuai dengan penelitian yang dilakukan oleh Ridho (2011), dan Rosy dan Gusti (2014) yang menyatakan bahwa dana perimbangan merupakan komponen utama dalam penentuan belanja daerah. Selain itu, hasil penelitian ini mendukung hasil kaijan Dessy (2015), yang secara lebih rinci menguraikan bahwa komponen-komponen dana perimbangan seperti DAU dan dana bagi hasil merupakan faktor yang signifikan berpengaruh terhadap belanja daerah.

Hasil estimasi menunjukan koefisien lain-lain pendapatan yang sah berpengaruh positif dan signifikan ( $p$-value $=0,0006$ ) terhadap belanja daerah pada level kepercayaan 1\%. Koefisien regresi sebesar 0,245 memberikan arti bahwa apabila terjadi kenaikan variabel lain-lain pendapatan yang sah sebesar 1 satuan, maka dalam kondisi cateris paribus, akan menaikkan jumlah belanja daerah sebesar 0,245 satuan (25\%). Hasil penelitian ini tidak searah dengan penelitian dari yang dilakukan oleh Yohanes (2016) di Kota Balikpapan yang menyatakan bahwa pengaruh lain-lain pendapatan yang sah tidak signifikan terhadap belanja daerah. Penjelasan yang logis atas kondisi ini adalah karena status Papua Barat sebagai daerah otonomi khusus yang mendapatkan dukungan dana otonomi khusus setiap tahunnya. Dana otonomi khusus yang dialokasikan melalui pos lain-lain pendapatan yang sah mengalami peningkatan yang signifikan setiap tahunnya, sehingga variasi belanja daerah juga ditentukan oleh sumber pembiayaan ini.

Secara keseluruhan, implikasi dari hasil penelitian ini adalah bahwa daerah-daerah kabupaten/ kota di Papua Barat masih perlu mengoptimalkan potensi-potensi ekonomi di wilayahnya agar dapat dimanfaatkan sebagai sumber-sumber peningkatan PAD. Selain itu, ketergantungan atas transfer dana dari pemerintah pusat juga perlu dikurangi agar semangat desentralisasi 
yang mengususng kemandirian fiskal dapat terealisasikan di setiap kabupaten/kota di Papua Barat.

\section{KESIMPULAN}

Penelitian ini bertujuan untuk menganalisis faktor-faktor yang mempengaruhi belanja daerah di kabupaten/kota di Papua Barat. Dari hasil analisis dapat disimpulkan beberapa hal sebagai berikut: Pertama, pengaruh PAD terhadap belanja daerah tidak signifikan. Hal ini berarti bahwa tinggi rendahnya PAD tidak menjadi penentu utama bagi pemerintah daerah dalam hal melakukan belanja daerah. Kedua, dana perimbangan lain-lain pendapatan yang sah menunjukkan pengaruh positif dan signifikan terhadap belanja daerah. Kondisi ini mengindikasikan bahwa dana transfer dari pemerintah pusat, baik dana perimbangan maupun dana otonomi khusus, masih merupakan komponen utama dalam belanja daerah pemerintah kabupaten/kota di Papua Barat.

Implikasi dari hasil penelitian ini adalah bahwa pemerintah daerah diharapkan dapat terus menggali semua potensi yang ada di daerah, sehingga mampu meningkatkan pendapatan asli daerah. Upaya-upaya peningkatan PAD sangat diperlukan guna memacu kemandirian fiskal daerah, dan pada saat yang bersamaan dapat mengurangi ketergantungan keuangan dari pemerintah pusat.

\section{DAFTAR PUSTAKA}

Badan Pusat Statistik (BPS) Kabupate/kota Provinsi Papua Barat 2011-2016. Kabupaten/kota Papua Barat Dalam Angka.

Badan Pusat Statistik (BPS) Provinsi Papua Barat. 2010-2015. Statistik Keuangan Pemerintah Daerah Papua Barat.

Dessy Tri Wulansari. 2015. Pengaruh Pendapatan Asli Daerah dan Dana Perimbangan terhadap Belanja Daerah serta analisis Flypaper Effect. Naskah Publikasi. Surakarta.

Halim, Abdul. 2007. Akuntansi Sektor Publik: Akuntansi Keuangan Daerah. Edisi 3. Jakarta, Indonesia : Salemba Empat.

Kuncoro, Murdajad. 2004. Otonomi dan Pembangunan Daerah. Jakarta. Erlangga
Lembaga Negara Republik Indonesia, Undangundang Nomor 32 tahun 2004, tentang Penerimaan Daerah.

Lembaga Negara Republik Indonesia, Undangundang Nomor 33 tahun 2004, tentang Perimbangan Keuangan Antara Pemerintah Pusat dan Pemerintah Daerah.

Maryanti, ulfi dan Endrawati. 2010. Pengaruh Pendapatan Asli Daerah (PAD), Dana Alokasi Umum (DAU) dan Dana Alokasi Khusus (DAK) terhadap pertumbuhan ekonomi: Studi Kasus Sumatera Barat. Jurnal Akuntansi dan Manajemen, vol 5, No2, Desember 2010.

Maspaitella, M. R. 2010. Pengaruh DAU dan PAD Terhadap Belanja Daerah (Studi Kasus Kabupaten/Kota di Tanah Papua). Lensa Ekonomi. Volume 4, Nomor 1 Juli 2010. 45-49.

Peraturan Pemerintah Republik Indonesia Nomor 37 Tahun 2005, tentang Pedoman Penyususnan Anggaran Pendapatan dan Belanja Daerah.

Peraturan Pemerintah Republik Indonesia Nomor 58 Tahun 2005, tentang Pengeolaan Keuangan Daerah

Rahmawati, Nur Indah. 2010. Pengaruh Pendapatan Asli Daerah (PAD) Dan Dana Alokasi Umum (DAU) Terhadap Alokasi Belanja Daerah Studi Pada Pemerintah Kabupaten dan Kota di Jawa Tengah. Fakultas Ekonomi, Universitas Diponegoro Semarang.

Ridho Argi. 2011. Analisis Belanja Daerah dan Faktor faktor Yang Mempengaruhinya di Kabupaten Dan Kota Provinsi Jawa Tengah Periode 2004-2009. Skripsi. Semarang.

Rosy Puspita Sari, I Gusti Bagus Indrajaya. 2014. Pengaruh Pendapatan Asli Daerah (PAD) dan Dana Perimbangan terhadap Alokasi Belanja Daerah Kabupaten Badung. E-Jurnal EP Unud, 3 [9]: 420-427.

Siahaan, Marihot. 2005. Pajak Daerah dan Retribusi Daerah. Jakarta Indonesia: Grafindo

Yohanes Eko Adventino. 2016. Pengaruh Pendapatan Asli Daerah, Dana Perimbangan, dan Lain-lain pendapatan daerah yang sah terhadap Belanja Daerah di Kota Balikpapan. Skripsi. Yogyakarta. 